\title{
Serum hepatitis B virus RNA levels as a predictor of HBeAg seroconversion during treatment with peginterferon alfa-2a
}

\author{
Wen Jia ${ }^{1,2}$ D, Men Qi Zhu' ${ }^{2}$, Xun Qi ${ }^{2}$, Ting Wang ${ }^{1,2}$, Xiao Wen ${ }^{1,2}$, Pei Dong Chen ${ }^{1,2}$, Qing Qi Fan ${ }^{1,2}$, \\ Wen-Hong Zhang ${ }^{2}$ and Ji Ming Zhang ${ }^{1,2^{*}}$
}

\begin{abstract}
Background: Hepatitis B e antigen ( $\mathrm{HBeAg}$ ) seroconversion represents an endpoint of treatment of chronic hepatitis B virus (HBV) infections.

Methods: We have studied whether levels of serum hepatitis B virus ribonucleic acid (HBV RNA) during pegylated interferon alfa-2a treatment might be helpful for predicting HBeAg seroconversion. $61 \mathrm{HBeAg-positive} \mathrm{chronic}$ hepatitis B (CHB) patients treated with pegylated interferon alfa-2a alone or in combination with adefovir (10 mg/ day) for 48 weeks were included in this retrospective analysis. Response was defined as HBeAg seroconversion at 24 weeks posttreatment. Receiver operating characteristic analyses were used to identify baseline and on-treatment HBV RNA levels associated with response.

Results: Twenty-two of 61 (36.1\%) patients achieved a response. Baseline HBV RNA levels were lower in responders than in nonresponders ( $4.55 \pm 1.19$ and $5.90 \pm 1.13$ copies $/ \mathrm{mL}$, respectively, $P=0.001$ ). Baseline HBV RNA cut off level (200,000 copies $/ \mathrm{mL}$ ) provided a positive predictive value (PPV) of $56.0 \%$ and a negative predictive value (NPV) of $77.8 \%$. HBV RNA level (3000 copies/mL) at week 12 provide a PPV of 75.0\% and a NPV of 82.8\%. Moreover, HBeAg seroconversion rates at 24 weeks posttreatment were significantly higher in patients with HBV RNA $\leq 200,000$ copies/ $\mathrm{mL}$ at baseline and HBV RNA $\leq 3000$ copies/mL at week 12 (92.9\%) versus others (12.5\%) (All $P<0.05$ ).

Conclusions: In Conclusions, serum HBV RNA levels may serve as a novel tool for prediction of HBeAg seroconversion during therapy with pegylated interferon alfa-2a in HBeAg-positive CHB patients.
\end{abstract}

Keywords: HBV RNA, Hepatitis B e antigens, Hepatitis B, Chronic

\section{Background}

Although effective vaccine against hepatitis B virus infection have been available for more than three decades, HBV infection remains a global health problem [1, 2]. Patients with chronic hepatitis B (CHB) have an increased risk of developing cirrhosis, hepatic decompensation, and hepatocellular carcinoma (HCC), which result in about 1 million deaths per year [3].

Antiviral treatment is effective in halting progression of $\mathrm{CHB}$ in many patients. Two classes of antiviral agents are

\footnotetext{
* Correspondence: jmzhang@fudan.edu.cn

Meng Qi Zhu is co-first author.

'Department of Infectious Diseases, Jing'An District Centre Hospital of Shanghai, Fudan University, Shanghai, China

${ }^{2}$ Department of Infectious Diseases, Huashan Hospital, Fudan University, Room 510, Building 5, 12 Middle Wulumuqi Road, Shanghai, China
}

available: nucleos(t)ide analogues (NA), such as entecavir, which inhibit the viral polymerase and interfere with viral replication, and interferon, including conventional and pegylated forms, which has antiviral and immunomodulatory effects. Pegylated interferon (PEG-IFN) remains an important first-line treatment option for $\mathrm{CHB}$, especially in hepatitis $\mathrm{B}$ e antigen ( $\mathrm{HBeAg}$ )-positive $\mathrm{CHB}$, because a long-term off-treatment sustained response can be achieved in about $25 \%$ of patients after a finite treatment course [4-6]. Recent international guidelines highlight that seroconversion of ( $\mathrm{HBeAg}$ ) is a surrogate endpoint that is considered to be a marker for durable therapeutic response and improved clinical outcome in HBeAg-positive patients with chronic hepatitis B [3, 7-9]. Additionally, patients who achieve HBeAg seroconversion have an 
increased chance of clearing $\mathrm{HBsAg}$ during long-term follow-up [10, 11]. However, only part of $\mathrm{HBeAg}$-positive $\mathrm{CHB}$ patients achieve $\mathrm{HBeAg}$ seroconversion at 24 weeks posttreatment. [4, 6] Early identification of responders would be of considerable benefit to clinicians, as it would allow therapy to be initiated only in patients likely to achieve a response, and to be modified in those patients unlikely to respond to the standard duration (48 weeks) of PEG-IFN monotherapy [5, 12-15].

Early studies on interferon-based therapies for chronic hepatitis B identified several factors that were associated with a higher likelihood of $\mathrm{HBeAg}$ seroconversion, including elevated serum alanine aminotransferase activity, lower levels of hepatitis B virus deoxyribonucleic acid (HBV DNA), and increased histologic activity in biopsy specimens [3, 16-19]. In addition, there is increasing interest in the association between HBV RNA level and response of patients treated with interferon and Polymerase Inhibitors [20-23]

During viral morphogenesis, pregenomic ribonucleic acid (pgRNA) is encapsidated into core particles and reverse transcribed by HBV DNA polymerase into relaxed circular DNA (rcDNA). Mature rcDNA-containing virions are then enveloped and released from infected hepatocytes [1, 24, 25]. Importantly, in addition to HBV DNA, hepatitis B virus ribonucleic acid (HBV RNA) has also been detected in the serum of chronic hepatitis $B$ (CHB) patient $[22,26,27]$. A possible association between serum HBV RNA levels and the presence of HBeAg was postulated in a previous study [27]. Recent studies revealed that a lower baseline plasma HBV RNA level was independently associated with response to
PEG-IFN [23]. These potential relationship prompted us to carry out a detailed investigation into serum HBV RNA levels during treatment with PEG-IFN.

\section{Methods \\ Aim}

Here, we studied whether levels of serum HBV RNA might be helpful for predicting $\mathrm{HBeAg}$ seroconversion during treatment of PEG-IFN alfa-2a.

\section{Study participants}

A total of 104 patients with chronic HBV infection receiving PEG-IFN alfa-2a (180 $\mu$ g/week) alone or in combination with adefovir (ADV) were enrolled in this retrospective study. Patients were recruited from Huashan Hospital, Fudan University from January 2012 to December 2015. The inclusion criteria were pre-treatment HBsAg positive for $>6$ months, $\mathrm{HBeAg}$ positive for $>6$ months, no exposure to NAs or interferon (including conventional and pegylated forms) within the 6 months. Patients with concomitant liver diseases including chronic hepatitis C or D infection, Wilson's disease, autoimmune hepatitis, primary biliary cirrhosis, decompensated cirrhosis, or those consuming a significant amount of alcohol ( $30 \mathrm{~g} /$ day for men, $20 \mathrm{~g} /$ day for women) were excluded. Patients were also excluded if they had evidence of anemia (hemoglobin levels $<11.5 \mathrm{~g} /$ $\mathrm{dL}$, for women and $<12.5 \mathrm{~g} / \mathrm{dL}$ for men), a neutrophil count $<1500$ cells $/ \mathrm{mm} 3$, or a platelet count $<90,000$ cells $/ \mathrm{mm}^{3}$ at screening. In total 61 patients who met the inclusion criteria were enrolled (Fig. 1).

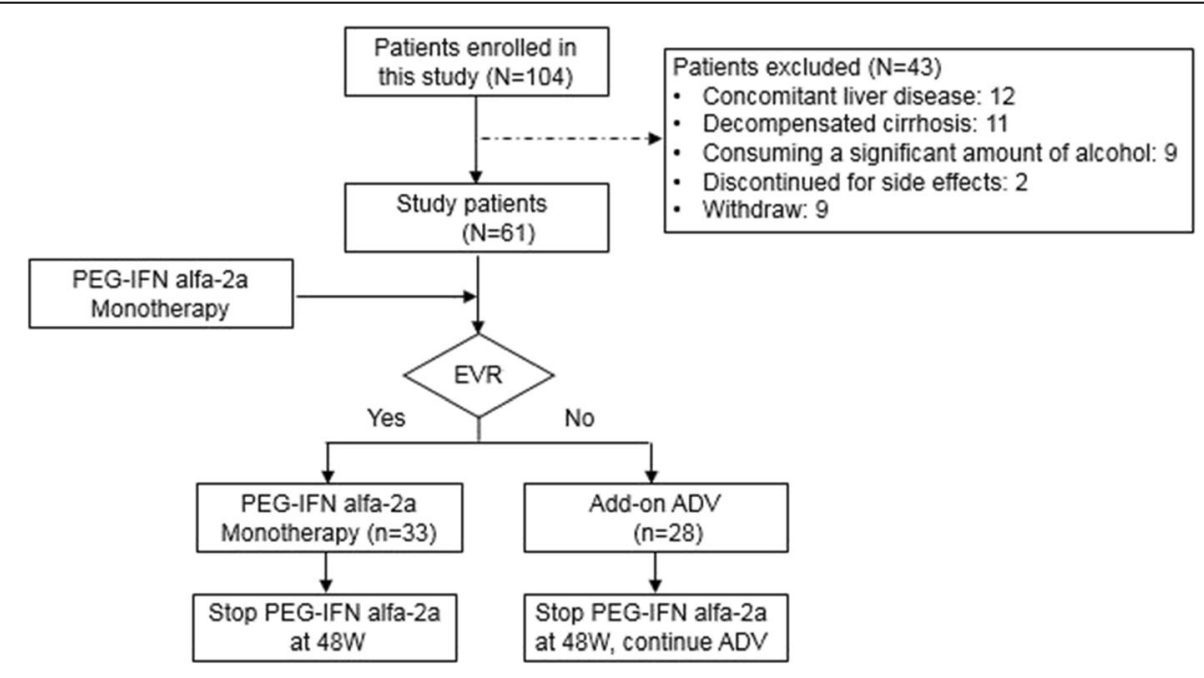

All study patients were followed up for 24 weeks posttreatment

Fig. 1 Flow chart of the study population and design. EVR: EVR was defined as HBV DNA decrease to < 100,000 copies/ml at week 12; ADV: adefovir; EVR: early virological response; PEG-IFN alfa-2a: Peginterferon alfa-2a 
The study was approved by the ethical committee of Jing'An District Centre Hospital of Shanghai (2017-18). All subjects gave informed consent for their participation in the study.

\section{Study design}

The protocol is shown in Fig. 1. Each patient started with PEG-IFN alfa-2a monotherapy. The first period proposed for monitoring was based on early virological response (EVR; HBV DNA decrease to <10,000 copies/ $\mathrm{ml}$ at week 12). We made the decision to add ADV at week 12, based on 12 week EVR. Patients who did not meet 12 week EVR required ADV add-on at week 12 . Subsequently, patients who treated with PEG-IFN alfa-2a monotherapy stopped PEG-IFN alfa-2a at week 48. However, those who add-on ADV stopped PEG-IFN alfa-2a administration at week 48 , but continued oral ADV therapy. $\mathrm{HBeAg}$, and antibody to the hepatitis B e antigen (anti-HBe), HBsAg, HBV DNA, HBV RNA were analyzed at baseline, during therapy at weeks 24,48 and 24 weeks posttreatment. Patients who exhibited HBeAg seroconversion were regarded as responders, whereas those who did not achieve seroconversion were considered non-responders.

\section{Safety}

We assessed the frequency, nature, and severity of adverse events, as well as changes in clinical laboratory parameters and vital signs from baseline. Adverse events and concomitant medications were recorded every 4 weeks. We analyzed adverse events according to the World Health Organization recommendations for toxicity grading, as adapted for chronic liver disease.

\section{Clinical and standard laboratory assessment}

Relevant clinical variables included age, sex, serum alanine aminotransferase (ALT), aspartate aminotransferase (AST) levels. ALT, AST were measured in UniCel Dxc 800 using Synchron system Kits (Beckman Coulter). Serum HBV DNA concentration was assessed by real-time polymerase chain reaction with a lower detection limit of 500 copies/mL (DAAN Diagnostics, Guangzhou, China). Serum HBsAg, HBeAg, and antibody to the hepatitis $B$ e antigen (anti-HBe) were measured using commercially available immunoassays (Abbott Laboratories, Chicago, IL). Serum HBsAg level's detection value ranges from 0.05 to $250 \mathrm{IU} / \mathrm{mL}$, and samples with an $\mathrm{HBsAg}$ level $>250 \mathrm{IU} / \mathrm{mL}$ required a 1:500 or greater dilution. All the test above are subject to strict quality control. Furthermore, our laboratory has passed the certificate from the College of American Pathologists (CAP).

\section{Quantification of HBV RNAs}

Total nucleic acids were isolated from $200 \mu \mathrm{L}$ serum using the High Pure Viral Nucleic Acid Kit (Roche Diagnostics) following the manufacturer's protocol and Quantification of HBV RNAs (Roche Diagnostics). Isolated HBV RNA was reverse transcribed using Quantscript RT Kits (Tiangen Biotech, Beijing, China) with Olige (dT). For detection of the resulting HBV cDNAs, the real-time PCR analyses were performed (ABI Prism 7300 Sequence Detection System (Applied Biosystems, Foster City, CA). A 25-IL volume of reaction mixture containing Taqmen PCR Master Mix (Applied Biosystems), $200 \mathrm{nM}$ of forward primer (5'-GGTCCCCTAGAAGA AGAACTCCCT-3', nucleotides nt 2361-2384), $200 \mathrm{nM}$ of reverse primer (CATTGAGTTCCCGAGATTGAGAT, nucleotides nt 2425-2448), Taqmen Probe (5'-FAMTCTCAATCGCCGCGTCGCAGA-TAMRA-3', nucleotides nt 2402-2422) and $2 \mathrm{uL}$ of cDNA solution was prepared. Amplification was performed after an activation step at $95^{\circ} \mathrm{C}$ for $1 \mathrm{~min}$ with 40 two-step cycles of $15 \mathrm{~s}$ at $95^{\circ} \mathrm{C}$ and of $30 \mathrm{~s}$ at $60^{\circ} \mathrm{C}$ ending with a cooling step down to $4{ }^{\circ} \mathrm{C}$. In parallel, one negative control, one positive control, and a re-calibrator were analyzed. Dilution series of plasmid-based positive controls were used to generate external calibration curves for quantitative analysis. The lower limit of detection was 500 copies $/ \mathrm{mL}$.

\section{Statistical analysis}

All data were processed using Stata 10.0 software (Stata Corporation, College Station, TX, USA). Categorical variables are expressed as number (\%), and quantitative variables are shown as mean \pm standard deviation for paired data or as median (Range) for unpaired data. Chi-square or Fisher's exact test was used to compare categorical variables, while for quantitative variables the $t$ test or Mann-Whitney's test (unpaired data) or the $t$ test or Wilcoxon's test (paired data) were used. Spearman's correlation coefficient (r) was used for correlation analysis. Additionally, Receiver operating characteristic curves were generated to compare the relative sensitivity and specificity of HBsAg, HBV DNA and HBV RNA as a predictor of $\mathrm{HBeAg}$ seroconversion. The cut off value was chosen according to the receiver operating characteristic curve when the sensitivity and specificity were both relatively high for the selective baseline factor. All tests were two-sided and used a significance level of 0.05 .

\section{Ethical approval}

The study was approved by the ethical committee of Jing'An District Centre Hospital of Shanghai (2017-18). All subjects gave informed consent for their participation in the study. 


\section{Results}

\section{Patient baseline clinical characteristics}

The baseline characteristics of the $61 \mathrm{HBeAg-positive}$ CHB patients are shown in Table 1 . The mean age was $34.0 \pm 8.0$ years (range, $23-57$ ), and $75 \%$ of them were male. The mean value of serum HBV DNA level and HBV RNA level were $6.72 \pm 1.91 \log _{10}$ copies/mL and $5.37 \pm 1.32 \log _{10}$ copies $/ \mathrm{mL}$, respectively. The mean value of serum HBsAg level was $3.89 \pm 0.71 \log _{10} \mathrm{IU} / \mathrm{mL}$. The ALT and AST values were $120.0 \mathrm{IU} / \mathrm{mL}$ (range 13$603 \mathrm{IU} / \mathrm{mL}$ ) and $89.0 \mathrm{IU} / \mathrm{mL}$ (range 21-435 IU/mL), respectively. HBV RNA levels were strongly correlated with HBV DNA and HBsAg levels. There was a strong inverse correlation between serum HBV RNA and HBV DNA (HBV RNA vs HBV DNA: $\mathrm{r}=0.684, P=0.004$, HBV RNA vs HBsAg: $r=0.521, P<0.001$ ) (Supple).

Relationship between HBeAg seroconversion and baseline serum HBV RNA levels, other serum markers of HBV replication

Of the 61 patients, 22 patients (36.1\%) exhibited $\mathrm{HBeAg}$ seroconversion at 24 weeks posttreatment (responders), and $39(52 \%)$ were non-responders. In terms of the probability of HBeAg seroconversion, there was no statistically significant difference between the PEG-IFNa2a alone and combination with adefovir (ADV combine with PEG-IFNa2a vs monotherapy: $9 / 28$ vs $13 / 33, P=$ 0.602). Baseline serum HBV RNA level for the responses and non-responsers were $4.55 \pm 1.19 \log _{10}$ copies $/ \mathrm{mL}$ (range 2.70-6.94 $\log _{10}$ copies $/ \mathrm{mL}$ ) and $5.90 \pm 1.13$ (range $3.10-7.52 \log _{10}$ copies $\left./ \mathrm{mL}\right)(P=0.001)$, respectively. Baseline serum HBV RNA levels were significantly lower for responses compared to non-responses. Furthermore, the baseline HBV DNA level and HBsAg level were significantly lower in responders than in non-responders (All $P<0.05$, Table 1 ). Additional, responsers were of younger age, higher ALT and AST levels (All $P<0.05$, Table 1). The percentage of men was similar between responders and non-responders.

\section{Receiver operating characteristics curves: prediction of} HBeAg seroconversion

Overall, HBV RNA, HBV DNA and HBsAg levels decreased consistently during treatment, we investigated the discriminatory capabilities of HBV RNA decline at baseline, weeks 12 and 24 for predicting response. Using receiver operating characteristic curve analysis, AUCs were $0.810,0.854$ and 0.817 for baseline, week 12 and 24 , respectively. For predicting response at 24 weeks posttreatment, the discriminatory values of absolute HBsAg and HBV DNA levels were also investigated. When balancing sensitivity and specificity, HBsAg is the best predictor of $\mathrm{HBeAg}$ seroconversion at baseline and week 24 while HBV RNA is the best predictor at week 12 (Fig. 2).

Next, Youden index was proceeded to investigate the optimal cutoff point. The optimal cutoff level of serum HBV RNA to predict response were 200,000, 3000 and 1000 copies/mL at baseline, week 12 and 24 respectively. Response rates and negative predictive value (NPV) were calculated for response at 24 weeks posttreatment (Table 2, Fig. 2). At baseline, $56.0 \%$ of patients with HBV RNA $\leqq 200,000$ copies/mL attained seroconversion. On the other hand, of who with HBV RNA > 200,000 copies/mL, only $22.2 \%$ achieved a response. Consequently, the NPV of HBV RNA $\leqq 200,000$ copies/mL is $77.8 \%$ for prediction of response (Table 2 Fig. 3a). At week 12, the PPV of HBV RNA $\leqq 3000$ copies/mL was $75.0 \%$ for prediction of response (Table 2 Fig. 3b). Furthermore, PPV and NPV of HBV RNA $\leqq 1000$ copies/mL at week 24 was 70.6 and $77.3 \%$, respectively (Table 2 Fig. 3c). Moreover, we examined the rates of response among patients with HBV RNA $\leqq 200,000$ copies/mL at baseline and $\leqq 3000$ copies/mL at week 12. The results showed that among the above subgroups, $92.9 \%$ achieved a response at 24 weeks posttreatment (Fig. 3d).

The optimal cutoff level of serum HBsAg to predict response were 8000,4000 and $2000 \mathrm{IU} / \mathrm{mL}$ at baseline,

Table 1 Baseline characteristics of responders and non-responders

\begin{tabular}{|c|c|c|c|c|}
\hline Variables & Overall populations & Responders & Non-responders & $P$ value \\
\hline Number & 61 & 22 & 39 & - \\
\hline Age (year) & $33.0(23-57)$ & $31.0(23-57)$ & $36.5(23-57)$ & 0.043 \\
\hline Male(\%) & $46(75)$ & $16(73)$ & $30(77)$ & 0.493 \\
\hline ALT (IU/L) & $120.0(13-603)$ & $175.0(43-575)$ & $88.0(13-603)$ & 0.025 \\
\hline AST (IU/L) & $89.0(21-435)$ & $140.0(36-435)$ & $68.0(21-399)$ & 0.031 \\
\hline HBV RNA ( $\log _{10}$ copies/mL) & $5.37 \pm 1.32$ & $4.55 \pm 1.19$ & $5.90 \pm 1.13$ & 0.001 \\
\hline HBV DNA ( $\log _{10}$ copies/mL) & $6.72 \pm 1.91$ & $5.76 \pm 2.24$ & $7.15 \pm 1.59$ & 0.036 \\
\hline $\mathrm{HBsAg}\left(\log _{10} \mathrm{IU} / \mathrm{mL}\right)$ & $3.89 \pm 0.71$ & $3.25 \pm 0.63$ & $4.24 \pm 0.53$ & $<0.001$ \\
\hline
\end{tabular}

$A L T$ alanine aminotransferase, $A S T$ aspartate aminotransferase, $H B s A g$ hepatitis $B$ surface antigen, $H B V D N A$ hepatitis $B$ deoxyribonucleic acid, $H B V R N A$ hepatitis $B$ ribonucleic acid

Data were expressed as mean values \pm standard deviation or median (range) 

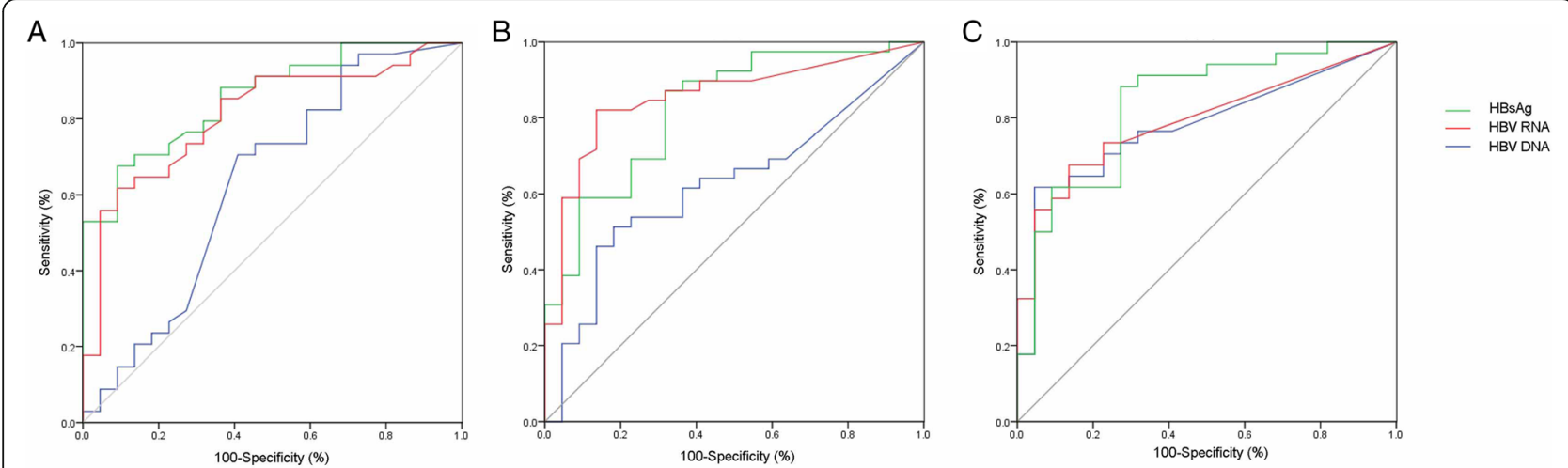

Fig. 2 Receiver operating characteristic curves predicting HBeAg seroconversion through posttreatment follow-up. Receiver operating characteristic curves for HBV RNA (red line), HBV DNA (blue line) and HBsAg (green line) as they predict HBeAg seroconversion, using data derived from their respective serum values at baseline, week 12, 24. a. Baseline data predict HBeAg seroconversion: Area under curve (AUC): HBV RNA 0.810; HBV DNA 0.630; HBsAg: 0.816; b. Week 12 data predict HBeAg seroconversion: AUC: HBV RNA 0.854; HBV DNA 0.678; HBsAg: 0.825; c. Week 24 data predict HBeAg seroconversion: HBV RNA 0.817; HBV DNA 0.779; HBsAg: 0.824

week 12 and 24 respectively. When we combine $\mathrm{HBV}$ RNA $>3000$ copies $/ \mathrm{mL}$ with $\mathrm{HBsAg}>4000 \mathrm{IU} / \mathrm{mL}$ at week 12 , the results showed that only $3.7 \%$ patients achived HBeAg seroconversion (NPV 96.3\%) (Fig. 3e, Additional file 1: Table S1).

\section{Factors associated with $\mathrm{HBeAg}$ seroconversion at 24 weeks posttreatment}

Younger age, lower level of HBV RNA and HBsAg at baseline, lower level of HBV RNA and HBsAg at week 12, lower level of HBV DNA, HBV RNA, HBsAg at week 24 (all $P<0.05$ ) were correlated with response at 24 weeks posttreatment by univariate analysis. After adjusting for different clinical parameters, factors independently associated with response at 24 weeks posttreatment included younger age $(\mathrm{OR}=0.687, P=0.040)$, ALT $\times \mathrm{ULN}$ at baseline ( $\mathrm{OR}=1.660, P=0.041)$, Baseline HBV RNA $\leqq 200,000$ copies $/ \mathrm{mL}(\mathrm{OR}=1.841, P=0.008)$, Baseline HBsAg $\leqq 8000 \mathrm{IU} / \mathrm{mL} \quad(\mathrm{OR}=3.791, P=0.003), \mathrm{HBV}$ RNA $\leqq 3000$ copies $/ \mathrm{mL}$ at week $12(\mathrm{OR}=12.458, P=$ $0.039)$ and $\mathrm{HBsAg} \leqq 2000 \mathrm{IU} / \mathrm{mL}$ at week $24(\mathrm{OR}=$ 3.297, $P=0.031$ ) (Table 3).
Relationship between sustained HBV DNA virological responders and HBV RNA

Sustained serum HBV DNA response, as well as $\mathrm{HBeAg}$ seroconversion in $\mathrm{HBeAg}$-positive $\mathrm{CHB}$ patients are the desired treatment endpoints. In our study, patients who exhibited HBV DNA $<10,000$ copies/mL at week 48 and 24 weeks posttreatment were regarded as virological responders (VR), whereas those who did not achieve it were considered non-VR. Baseline serum HBV RNA levels were significantly lower for virological response (VR) compared to non-VR $(P=0.013)$. Similarly, on treatment serum HBV RNA levels were significantly lower for VR compared to non-VR (all $P<0.05$ ) (Table 4). Using receiver operating characteristic curve analysis for predicting VR, HBV RNA at week 24 is the best predictor (AUC 0.797, Standard Error 0.079, $P<0.001$ ) (Fig. 4). The optimal cutoff level of serum HBV RNA at week 24 to predict VR were $\log _{10}$ 3.76, the nearest two thousand level is 5000 copies/mL, yielded a PPV of $68.1 \%$ for HBV RNA $\leq$ 5000 copies $/ \mathrm{mL}$, of whom $29.5 \%$ achieved VR yielding a NPV of $70.5 \%$.

Table 2 Levels of serum HBV RNA at baseline and on-treatment: relationship to response at 24 weeks posttreatment

\begin{tabular}{lllll}
\hline & HBV RNA (copies/mL) & Total No. of patients & No. of patients with HBeAg seroconversion & $\begin{array}{l}\text { Percentage of patients with HBeAg } \\
\text { seroconversion }\end{array}$ \\
\hline Baseline & $\leqq 200,000$ & 25 & 14 & $56.0 \%$ \\
& $>200,000$ & 36 & 8 & $22.2 \%$ \\
Week 12 & $\leqq 3000$ & 20 & 15 & $75.0 \%$ \\
& $>3000$ & 41 & 7 & $17.1 \%$ \\
Week 24 & $\leqq 1000$ & 17 & 12 & $70.6 \%$ \\
& $>1000$ & 44 & 10 & $22.7 \%$ \\
\hline
\end{tabular}




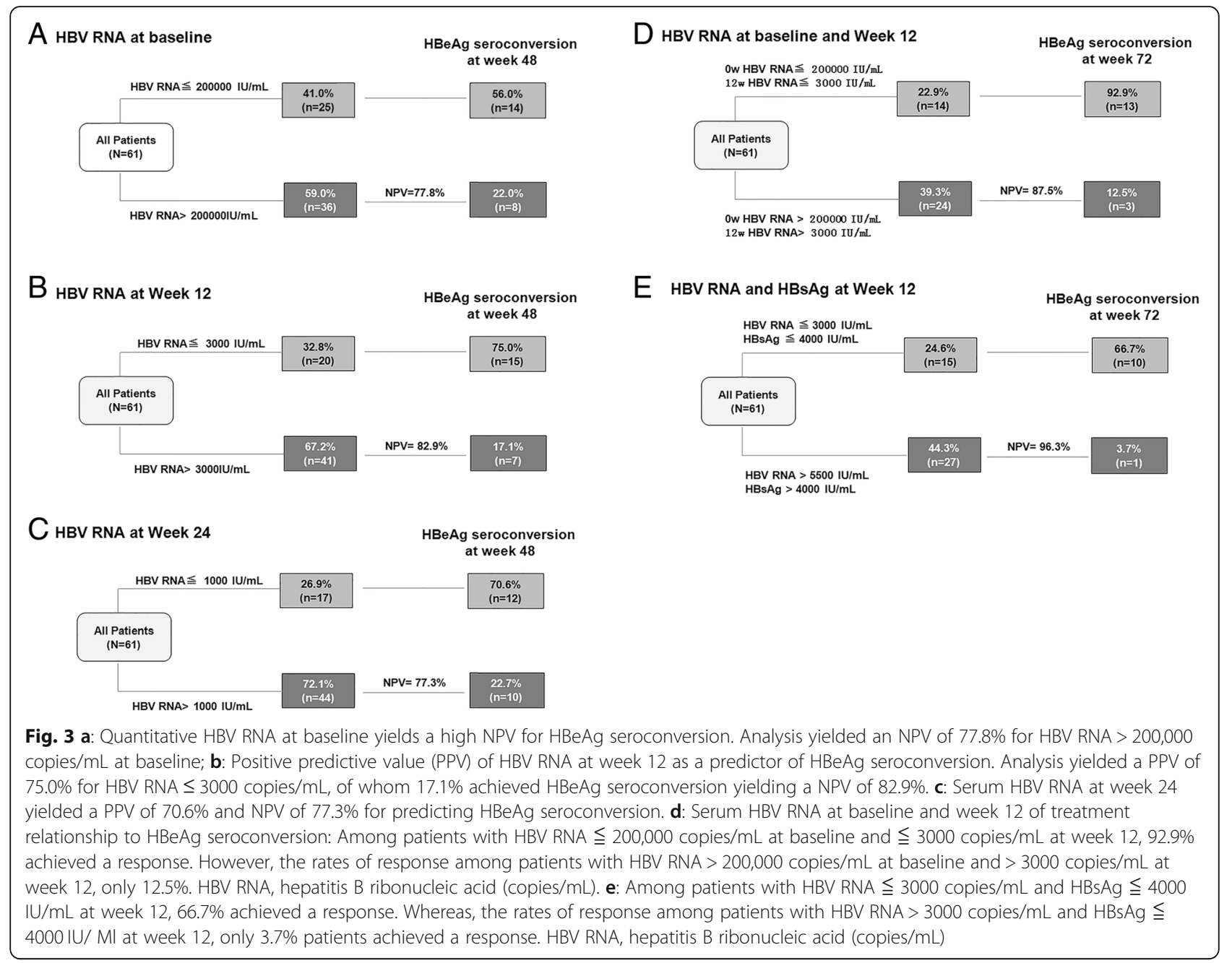

Table 3 Multivariate and univariate analyses of factors associated with HBeAg seroconversion at 24 weeks posttreatment

\begin{tabular}{|c|c|c|c|c|c|c|}
\hline \multirow[t]{2}{*}{ Variables } & \multicolumn{3}{|c|}{ Univariate analysis } & \multicolumn{3}{|c|}{ Multivariate analysis } \\
\hline & Odd ratio & 95\% confidence interval & $P$ value & Odd ratio & 95\% confidence interval & $P$ value \\
\hline Sex (male) & 0.810 & $(0.241-2.651)$ & 0.715 & & & \\
\hline Age (years) & 0.896 & $(0.818-0.981)$ & 0.018 & 0.687 & $(0.384-0.850)$ & 0.040 \\
\hline $\operatorname{ALT}(U / L) \times U L N$ at baseline & 1.315 & $(0.977-1.768)$ & 0.071 & 1.660 & $(1.097-2.875)$ & 0.041 \\
\hline AST $(U / L) \times U L N$ at baseline & 1.298 & $(0.849-1.501)$ & 0.087 & & & \\
\hline Baseline HBV DNA $\leq 30,000,000$ copies $/ \mathrm{mL}$ copies $/ \mathrm{mL}$ & 1.636 & $(0.542-4.937)$ & 0.382 & & & \\
\hline Baseline HBV RNA $\leq 200,000$ copies/mL & 3.818 & $(1.228-12.871)$ & 0.021 & 1.841 & $(1.175-3.708)$ & 0.008 \\
\hline Baseline $\mathrm{HBsAg} \leq 8000 \mathrm{IU} / \mathrm{mL}$ & 6.001 & $(1.787-20.150)$ & 0.004 & 3.791 & $(1.969-25.358)$ & 0.003 \\
\hline HBV DNA $\leq 200,000$ copies/mL at week 12 & 3.429 & $(0.969-12.131)$ & 0.056 & & & \\
\hline HBV RNA $\leq 3000$ copies/mL at week 12 & 5.357 & $(1.605-17.879)$ & 0.006 & 12.458 & $(3.969-80.494)$ & 0.039 \\
\hline $\mathrm{HBsAg} \leq 4000 \mathrm{IU} / \mathrm{mL}$ at week 12 & 7.363 & $(2.150-25.223)$ & 0.001 & & & \\
\hline HBV DNA $\leq 30,000$ copies/mL at week 24 & 12.681 & $(1.783-60.873)$ & 0.012 & & & \\
\hline HBV RNA $\leq 1000$ copies/mL at week 24 & 6.500 & $(1.915-22.051)$ & 0.003 & & & \\
\hline $\mathrm{HBsAg} \leq 2000 \mathrm{IU} / \mathrm{mL}$ at week 24 & 7.519 & $(2.232-25.316)$ & 0.001 & 3.297 & $(1.346-21.391)$ & 0.031 \\
\hline
\end{tabular}

ALT alanine aminotransferase, AST aspartate aminotransferase, $H B s A g$ hepatitis B surface antigen, HBV DNA hepatitis B deoxyribonucleic acid, $H B V$ RNA hepatitis B ribonucleic acid 
Table 4 HBV RNA levels in virological responders and non virological responders

\begin{tabular}{llll}
\hline Variables & VR & Non-VR & $P$ value \\
\hline Number & 42 & 19 & - \\
Baseline HBV RNA $\left(\log _{10}\right.$ copies $\left./ \mathrm{mL}\right)$ & $4.81 \pm 1.39$ & $6.20 \pm 0.80$ & 0.013 \\
Week 12 HBV RNA $\left(\log _{10}\right.$ copies $\left./ \mathrm{mL}\right)$ & $3.35 \pm 0.80$ & $4.93 \pm 0.86$ & $<0.001$ \\
Week $24 \mathrm{HBV}$ RNA $\left(\log _{10}\right.$ copies $\left./ \mathrm{mL}\right)$ & $3.04 \pm 0.67$ & $4.49 \pm 1.04$ & $<0.001$ \\
Week 36 HBV RNA $\left(\log _{10}\right.$ copies $\left./ \mathrm{mL}\right)$ & $2.79 \pm 0.21$ & $3.65 \pm 0.75$ & $<0.001$ \\
Week 48 HBV RNA $\left(\log _{10}\right.$ copies $\left./ \mathrm{mL}\right)$ & $2.84 \pm 0.40$ & $3.15 \pm 0.47$ & 0.011
\end{tabular}

HBV RNA hepatitis $B$ ribonucleic acid, VR patients who achieved sustain virological response, non-VR, patients who didn't achieve sustain virological response

Data were expressed as mean values \pm standard deviation

\section{Discussion}

Nowadays, more and more doctors are taking the initiative in individualized treatment for chronic hepatitis B patients. With the purpose of taking individualized treatment, it is important to evaluate the baseline status of each patient at the start of treatment and to then decide which antiviral drug is the best choice. For those patients who are not likely to benefit from PEG-IFN therapy, an early switch to NA is essential. Our intention was to find a new predictive marker for serologic response in $\mathrm{HBeAg}$ positive CHB patients during treated with Peg-IFN alfa-2a. In the present study we have analyzed the level of HBV RNA in serial serum samples derived from chronically HBV infected patients receiving
Peg-IFN. Then, we focused on baseline and on-treatment predictors for $\mathrm{HBeAg}$ seroconversion at 24 weeks posttreatment week.

Previous study confirmed that the HBV RNA detected in serum is pgRNA. We set up a method to quantify HBV RNA in serum specimens by using a specific primers which carries the polyadenylation signal downstream of the $\mathrm{HBx}$ open reading frame (ORF) at position nt 2361. HBV RNA were all detectable from all serum of baseline, which were similar from the study before [23].

The results showed baseline HBV RNA levels were strongly correlated with HBV DNA and HBsAg levels in untreated patients (HBV RNA vs HBV DNA: $r=0.684$, $P=0.004$, HBV RNA vs HBsAg: $\mathrm{r}=0.521, P<0.001$ ), an observation which was also previously reported supporting the hypothesis that polyadenylated serum HBV RNA is a marker of HBV replication [21, 23, 28].

We observed that baseline HBV RNA levels were lower in patients achieving response than in non-responders $(4.55 \pm 1.19$ and $5.90 \pm 1.13$ copies $/ \mathrm{mL}$, respectively, $P=0.001)$. Moreover, Baseline HBV RNA cut off level $(200,000$ copies $/ \mathrm{mL})$ provided a positive predictive value (PPV) of $56.0 \%$ and a negative predictive value (NPV) of $77.8 \%$ for response. In additional, baseline HBV RNA $\leqq 200,000$ copies/mL was an independent factor associated with response (OR 1.841, $P=$ 0.008). The results were similar with the Florian's research [29]. Younger age, higher level of ALT, lower level

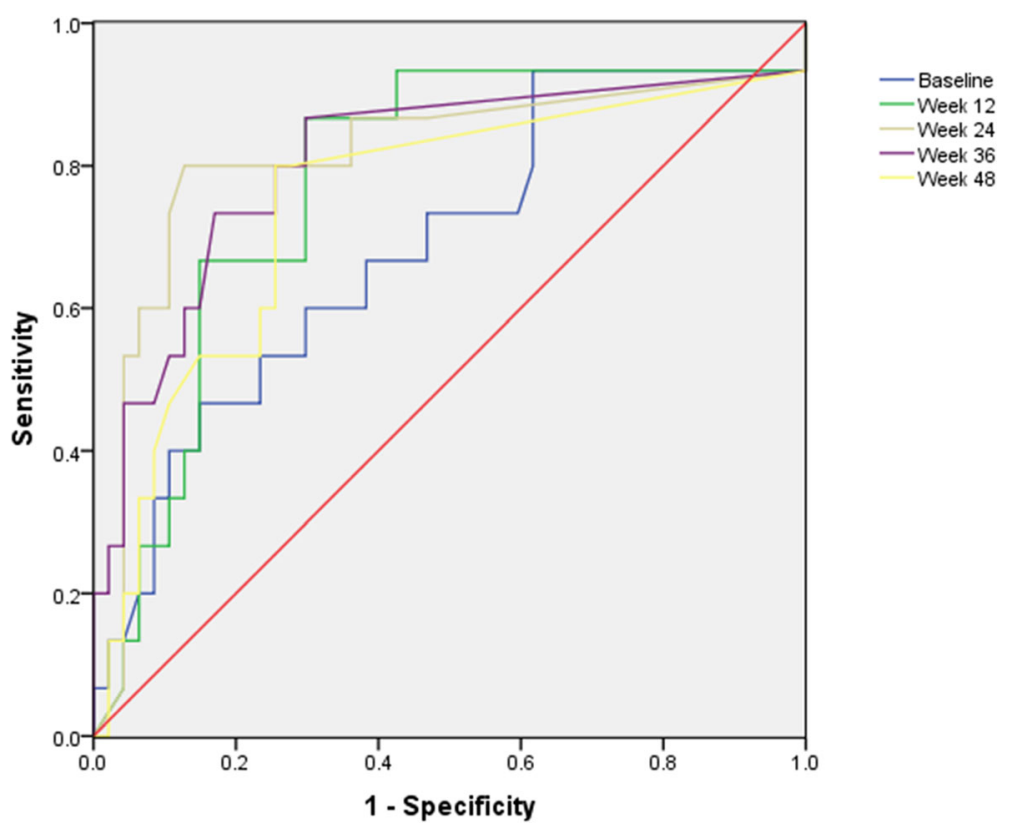

Fig. 4 Receiver operating characteristic curves predicting sustained virological response. Receiver operating characteristic curves for HBV RNA at baseline (blue line), HBV RNA at week 12 (green line), HBV RNA at week 24 (grey), HBV RNA at week 36 (purple), HBV RNA at week 48 (yellow line) as they predict sustained virological response. AUC: HBV RNA at baseline 0.685; HBV RNA at week 12 0.777; HBV RNA at week 24 0.797; HBV RNA at week 360.766 , HBV RNA at week 480.747 
of HBsAg and HBV DNA at baseline were independently related to response as expected, which were similar with previous studies $[5,6,30,31]$.

In line with these observations was the stronger decline in HBV RNA levels in responsers after treatment with non-responders. ROC curves showed that AUC of HBV RNA (0.854) was superior to that of HBsAg (0.825) in predicting response at week 12 . What was consistently to the study before [29].

Furthermore, we examined the rates of response among patients with HBV RNA > 200,000 copies/mL at baseline and $>3000$ copies $/ \mathrm{mL}$ at week 12 . The results showed that among the above subgroups, only $12.5 \%$ (3/ 24) achieved a response (NPV 87.5\%) (Fig. 3d). This findings indicate that prediction of nonresponse to PEG-IFN alfa-2a is possible as early as week 12 and comparable to HBsAg monitoring [31]. The factors affecting $\mathrm{HBeAg}$ seroconversion 24 weeks posttreatment were analyzed in our study. Meanwhile, only $3.7 \%$ patients with HBV RNA > 3000 copies/mL with $\mathrm{HBsAg}>$ $4000 \mathrm{IU} / \mathrm{mL}$ at week 12 achived $\mathrm{HBeAg}$ seroconversion. The results advised the subgroup should change the treatment.

The factors affecting HBeAg seroconversion at 24 weeks posttreatment were analyzed in our study. Multivariate analysis showed that HBV RNA < 200,000 copies/ $\mathrm{mL}$ at baseline, HBV RNA $<3000$ copies $/ \mathrm{mL}$ at week 12 were independent predictors for $\mathrm{HBeAg}$ seroconversion at 24 weeks post-PEG-IFN treatment, with the latter being the strongest predictor $(\mathrm{OR}=12.458 P=0.039)$. Furthermore, younger age, ALT $\times$ ULN at baseline, HBsAg at baseline, HBsAg at week 24 were independent predictors for HBeAg seroconversion at 24 weeks posttreatment other than HBV RNA. These findings were consistent with the research before [13, 30, 32].

Sustained virological response in $\mathrm{HBeAg}$-positive $\mathrm{CHB}$ patients are the desired treatment endpoints. Sustained virological response after Peg-IFNa is usually associated with remission of the liver disease. In our present study, HBV RNA levels were significantly lower, at all time points for virological response (VR) compared to non-VR (all $P<0.05$ ). AUC of HBV RNA at week 24 is 0.797, showing PPV 68.1\% and NPV 70.5\% for 5000 copies $/ \mathrm{mL}$. For the reason that risk of HBV reactivation seems to been there for years. All such patients require long-term follow-up because of the risk of exacerbation with development of $\mathrm{HBeAg}$ negative $\mathrm{CHB}$ or even of $\mathrm{HBeAg}$ seroconversion in initially $\mathrm{HBeAg}$ positive patients [33]. At the same time, the patients only follow-up for 24 weeks posttreatment in our study. Thus, further studies with long term follow-up are needed to proceed.

Interest in HBV RNA as a marker of sustained response to interferon-based therapy has been based upon studies that showed a positive association between HBV
RNA and covalently closed circular DNA (cccDNA) [34-36]. CccDNA reflects the number of hepatocytes infected with the virus and acts as a template for transcription of viral genes [37-39]. The ongoing presence of cccDNA in hepatocytes even when serum HBV DNA levels are undetectable is responsible for the persistence and potential recurrence of HBV infection [40]. The immunomodulatory activity of interferon results in activation of cytotoxic $\mathrm{T}$ cells [41]. These cells are important in clearing infected hepatocytes and thereby act to reduce levels of cccDNA [42]. Taken together, these data suggest that HBV RNA level is an appropriate way to monitor the ongoing immune clearance of infected hepatocytes and elimination of cccDNA mediated by PEG-IFN alfa-2a. Interestingly enough, serum HBV RNA may better reflect the activity of intrahepatic cccDNA than serum HBV DNA during NA treatment. It is based on the fact that formation of rcDNA is blocked by NA. However, HBV RNA virion-like particle is not be affected [22, 43, 44]. Thus, HBV RNA has been found to be associated with HBeAg seroconversion [21, 45], response to NA treatment $[43,46]$, the safe of discontinue of NA treatment [22, 47], the emergence of mutant [48].

It is advised that HBV RNA level in serum could be used as a new tool for predicting response to PEG-IFN alfa-2a treatment in HBeAg-positive patients. The prediction of nonresponse to PEG-IFN alfa-2a is possible as early as week 12 . According to our results, baseline HBV RNA levels combined with week 12 could further improve the predictive value for predicting response. Nonetheless, information on HBV genotypes was not available and the limited number of patients achieving $\mathrm{HBeAg}$ seroconversion included in our study represents a limitation. Therefore further studies on serum HBV RNA as a response marker are needed to confirm these findings.

\section{Conclusions}

In conclusion, we showed that HBV RNA is detectable in serum specimens. A 48-week course of PEG-IFN alfa-2a results in a significant decline in serum HBV RNA in patients with $\mathrm{HBeAg}$-positive CHB. Patients who with HBV RNA $>200,000$ copies $/ \mathrm{mL}$ at baseline and $>3000$ copies $/ \mathrm{mL}$ at week 12 have a low chance of achieving $\mathrm{HBeAg}$ seroconversion 24 weeks posttreatment, and should therefore be considered for treatment discontinuation. Meanwhile, patients with HBV RNA > 3000 copies $/ \mathrm{mL}$ and $\mathrm{HBsAg}>4000 \mathrm{IU} / \mathrm{mL}$ at week 12 should change the treatment as well.

\section{Additional file}

Additional file 1: Figure S1. Scatter plots showing levels of HBV RNA and HBsAg. HBV RNA and HBV DNA (both in $\log _{10}$ copies $/ \mathrm{mL}$ ) before PEG-IFN alfa-2a treatment in $61 \mathrm{HBeAg}$ positive patients. A. The level of 
HBV RNA was significantly correlated with HBV DNA before treatment ( $=0.684, P=0.004) ; B$. The level of HBV RNA was significantly correlated with HBsAg before treatment $(r=0.521, P<0.001)$. $r$ : Pearson's correlation coefficient; $P: p$ value of the correlation t-test. Table S1. Levels of serum HBV RNA, HBsAg, HBV DNA relationship to response at 24 weeks posttreatment. (DOCX $129 \mathrm{~kb})$

\section{Abbreviations}

ADV: Adefovir; CHB: Chronic hepatitis B; EVR: Early virological response; HBeAg: Hepatitis B e antigen; HBV DNA: Hepatitis B virus deoxyribonucleic acid; HBV RNA: Hepatitis B virus ribonucleic acid; HBV RNA: Hepatitis B virus ribonucleic acid; HBV: hepatitis B virus; HCC: Hepatocellular carcinoma; NA: nucleos(t)ide analogues; PEG-IFN: Pegylated interferon; pgRNA: Pregenomic ribonucleic acid; rcDNA: Relaxed circular DNA

\section{Acknowledgements}

We thank Dr. Xiao Qin Wang (Department of Hematology, Fudan University) for her helpful suggestions during the study.

\section{Funding}

This study was supported by the National Natural Science Foundation of China (No. 81871640), National "13th five-year plan" major infectious disease project (No. 2017ZX10202203007 and No.2017ZX10202202), National Science and Technology Major Project of China (No.281672009 and No.81471933), Construction of key specialties in Shanghai (No.ZK2015B12) and Jing'An Health Bureau (No.JW2C2014G06).

\section{Availability of data and materials}

Serum HBsAg, HBeAg, and antibody to the hepatitis B e antigen (anti-HBe) were measured using commercially available immunoassays (Abbott Laboratories, Chicago, IL). Total nucleic acids separated in the study High Pure Viral Nucleic Acid Kit (Roche Diagnostics) (05204909001). Isolated HBV RNA was reverse transcribed using Quantscript RT Kits (Tiangen Biotech, Beijing, China) (KR103-04). The real-time PCR analyses were performed (ABI Prism 7300 Sequence Detection System (Applied Biosystems, Foster City, CA), using SuperReal Premix Kits (Tiangen Biotech, Beijing, China) (FP206-02).

\section{Authors' contributions}

The respective roles of each author are as follows. Wen Jia, Meng Qi Zhu were responsible for and data analysis, Xun Qi, Ting Wang were responsible for database management. Xiao Wen and Pei Dong Chen were responsible for patients follow-up. Ji Ming Zhang and Wen Hong Zhang were responsible for study design. Wen Jia and Ji Ming Zhang wrote the manuscript. All authors read and approved the final manuscript.

\section{Ethics approval and consent to participate}

The study was approved by the ethical committee of Jing'An District Centre Hospital of Shanghai (2017-18). All subjects gave informed consent for their participation in the study.

\section{Consent for publication}

Not applicable.

\section{Competing interests}

The authors declare no conflicts of interest relevant to the manuscript.

\section{Publisher's Note}

Springer Nature remains neutral with regard to jurisdictional claims in published maps and institutional affiliations.

Received: 20 December 2018 Accepted: 25 March 2019

Published online: 07 May 2019

\section{References}

1. Ganem D, Prince AM. Hepatitis B virus infection--natural history and clinical consequences. N Engl J Med. 2004;350:1118-29.

2. Wright TL, Lau JY. Clinical aspects of hepatitis B virus infection. Lancet. 1993; 342:1340-4.

3. EASL clinical practice guidelines. Management of chronic hepatitis B virus infection. J Hepatol. 2012;57:167-85.
4. Buster EH, Flink HJ, Cakaloglu Y, Simon K, Trojan J, Tabak F, So TM, Feinman SV, Mach T, Akarca US, et al. Sustained HBeAg and HBsAg loss after longterm follow-up of HBeAg-positive patients treated with peginterferon alpha2b. Gastroenterology. 2008;135:459-67.

5. Janssen $\mathrm{HL}$, van Zonneveld M, Senturk H, Zeuzem S, Akarca US, Cakaloglu Y, Simon C, So TM, Gerken G, de Man RA, et al. Pegylated interferon alfa-2b alone or in combination with lamivudine for HBeAg-positive chronic hepatitis B: a randomised trial. Lancet. 2005;365:123-9.

6. Lau GK, Piratvisuth T, Luo KX, Marcellin P, Thongsawat S, Cooksley G, Gane E, Fried MW, Chow WC, Paik SW, et al. Peginterferon alfa-2a, lamivudine, and the combination for HBeAg-positive chronic hepatitis B. N Engl J Med. 2005; 352:2682-95.

7. Liaw YF, Leung N, Kao JH, Piratvisuth T, Gane E, Han KH, Guan R, Lau GK, Locarnini S. Asian-Pacific consensus statement on the management of chronic hepatitis B: a 2008 update. Hepatol Int. 2008;2:263-83.

8. Liaw YF, Kao JH, Piratvisuth T, Chan HL, Chien RN, Liu CJ, Gane E, Locarnini S, Lim SG, Han KH, et al. Asian-Pacific consensus statement on the management of chronic hepatitis B: a 2012 update. Hepatol Int. 2012;6:531-61.

9. Lok AS, McMahon BJ. Chronic hepatitis B: update 2009. Hepatology. 2009;50: $661-2$.

10. Moucari R, Korevaar A, Lada O, Martinot-Peignoux M, Boyer N, Mackiewicz V, Dauvergne A, Cardoso AC, Asselah T, Nicolas-Chanoine MH, et al. High rates of $\mathrm{HBsAg}$ seroconversion in $\mathrm{HBeAg}$-positive chronic hepatitis B patients responding to interferon: a long-term follow-up study. J Hepatol. 2009;50: 1084-92.

11. van Zonneveld M, Honkoop P, Hansen BE, Niesters HG, Darwish MS, de Man RA, Schalm SW, Janssen HL. Long-term follow-up of alpha-interferon treatment of patients with chronic hepatitis B. Hepatology. 2004;39:804-10.

12. Zhou P, Yang F, Wang J, Mao R, Qi X, Huang Y, Zhang J. Improved efficacy of a pegylated interferon-alpha-2a stepwise optimization treatment strategy in the treatment of hepatitis B e antigen-positive chronic hepatitis B patients. Medicine (Baltimore). 2015;94:e730.

13. Fried MW, Piratvisuth T, Lau GK, Marcellin P, Chow WC, Cooksley G, Luo KX, Paik SW, Liaw YF, Button P, Popescu M. HBeAg and hepatitis B virus DNA as outcome predictors during therapy with peginterferon alfa-2a for HBeAgpositive chronic hepatitis B. Hepatology. 2008;47:428-34.

14. Marcellin P, Wursthorn K, Wedemeyer H, Chuang WL, Lau G, Avila C, Peng CY, Gane E, Lim SG, Fainboim H, et al. Telbivudine plus pegylated interferon alfa-2a in a randomized study in chronic hepatitis B is associated with an unexpected high rate of peripheral neuropathy. J Hepatol. 2015;62:41-7.

15. Xie Q, Zhou H, Bai X, Wu S, Chen JJ, Sheng J, Xie Y, Chen C, Chan HL, Zhao M. A randomized, open-label clinical study of combined pegylated interferon alfa-2a (40KD) and entecavir treatment for hepatitis B "e" antigenpositive chronic hepatitis B. Clin Infect Dis. 2014;59:1714-23.

16. Marcellin P, Bonino F, Yurdaydin C, Hadziyannis S, Moucari R, Kapprell HP, Rothe V, Popescu M, Brunetto MR. Hepatitis B surface antigen levels: association with 5-year response to peginterferon alfa-2a in hepatitis B eantigen-negative patients. Hepatol Int. 2013;7:88-97.

17. Sonneveld MJ, Hansen BE, Piratvisuth T, Jia JD, Zeuzem S, Gane E, Liaw YF Xie Q, Heathcote EJ, Chan HL, Janssen HL. Response-guided peginterferon therapy in hepatitis B e antigen-positive chronic hepatitis B using serum hepatitis B surface antigen levels. Hepatology. 2013;58:872-80.

18. Sarri G, Westby M, Bermingham S, Hill-Cawthorne G, Thomas H. Diagnosis and management of chronic hepatitis B in children, young people, and adults: summary of NICE guidance. BMJ. 2013;346:f3893.

19. Rijckborst V, Hansen BE, Ferenci P, Brunetto MR, Tabak F, Cakaloglu Y, Lanza $A G$, Messina $V$, lannacone $C$, Massetto $B$, et al. Validation of a stopping rule at week 12 using HBsAg and HBV DNA for HBeAg-negative patients treated with peginterferon alfa-2a. J Hepatol. 2012;56:1006-11.

20. Huang YW, Chayama K, Tsuge M, Takahashi S, Hatakeyama T, Abe H, Hu JT, Liu CJ, Lai MY, Chen DS, et al. Differential effects of interferon and lamivudine on serum HBV RNA inhibition in patients with chronic hepatitis B. Antivir Ther. 2010;15:177-84.

21. van Bommel F, Bartens A, Mysickova A, Hofmann J, Kruger DH, Berg T, Edelmann A. Serum hepatitis B virus RNA levels as an early predictor of hepatitis B envelope antigen seroconversion during treatment with polymerase inhibitors. Hepatology. 2015;61:66-76.

22. Tsuge M, Murakami E, Imamura M, Abe H, Miki D, Hiraga N, Takahashi S, Ochi $H$, Nelson HC, Ginba H, et al. Serum HBV RNA and HBeAg are useful markers for the safe discontinuation of nucleotide analogue treatments in chronic hepatitis B patients. J Gastroenterol. 2013;48:1188-204. 
23. Jansen $L$, Kootstra NA, van Dort KA, Takkenberg RB, Reesink HW, Zaaijer HL Hepatitis $B$ virus Pregenomic RNA is present in Virions in plasma and is associated with a response to Pegylated interferon alfa-2a and Nucleos(t)ide analogues. J Infect Dis. 2016;213:224-32.

24. Pan CQ, Zhang JX. Natural history and clinical consequences of hepatitis B virus infection. Int J Med Sci. 2005;2:36-40.

25. Schadler S, Hildt E. HBV life cycle: entry and morphogenesis. Viruses. 2009;1: 185-209.

26. Kock J, Theilmann L, Galle P, Schlicht HJ. Hepatitis B virus nucleic acids associated with human peripheral blood mononuclear cells do not originate from replicating virus. Hepatology. 1996;23:405-13.

27. Su Q, Wang SF, Chang TE, Breitkreutz R, Hennig H, Takegoshi K, Edler L, Schroder $\mathrm{CH}$. Circulating hepatitis B virus nucleic acids in chronic infection : representation of differently polyadenylated viral transcripts during progression to nonreplicative stages. Clin Cancer Res. 2001;7:2005-15.

28. Rokuhara A, Matsumoto A, Tanaka E, Umemura T, Yoshizawa K, Kimura T, Maki N, Kiyosawa K. Hepatitis B virus RNA is measurable in serum and can be a new marker for monitoring lamivudine therapy. J Gastroenterol. 2006; 41:785-90.

29. van Bommel F, van Bommel A, Krauel A, Wat C, Pavlovic V, Yang L, Deichsel D, Berg T, Bohm S. Serum HBV RNA as a predictor of Peginterferon alfa-2a response in patients with $\mathrm{HBeAg}$-positive chronic hepatitis B. J Infect Dis. 2018;218:1066-74.

30. Piratvisuth T, Marcellin P, Popescu M, Kapprell HP, Rothe V, Lu ZM. Hepatitis $B$ surface antigen: association with sustained response to peginterferon alfa2a in hepatitis B e antigen-positive patients. Hepatol Int. 2013;7:429-36.

31. Wang YC, Yang SS, Su CW, Wang YJ, Lee KC, Huo TI, Lin HC, Huang YH. Predictors of response to pegylated interferon in chronic hepatitis $\mathrm{B}$ : a realworld hospital-based analysis. Sci Rep. 2016;6:29605.

32. Sonneveld MJ, Rijckborst V, Boucher CA, Hansen BE, Janssen HL. Prediction of sustained response to peginterferon alfa- $2 b$ for hepatitis $B$ e antigenpositive chronic hepatitis B using on-treatment hepatitis B surface antigen decline. Hepatology. 2010;52:1251-7.

33. EASL 2017 Clinical practice guidelines on the management of hepatitis $B$ virus infection. J Hepatol 2017, 67:370-398.

34. Kimura T, Rokuhara A, Sakamoto Y, Yagi S, Tanaka E, Kiyosawa K, Maki N. Sensitive enzyme immunoassay for hepatitis B virus core-related antigens and their correlation to virus load. J Clin Microbiol. 2002;40:439-45.

35. Rokuhara A, Tanaka E, Matsumoto A, Kimura T, Yamaura T, Orii K, Sun X, Yagi S, Maki N, Kiyosawa K. Clinical evaluation of a new enzyme immunoassay for hepatitis B virus core-related antigen; a marker distinct from viral DNA for monitoring lamivudine treatment. J Viral Hepat. 2003;10:324-30.

36. Tanaka E, Matsumoto A, Suzuki F, Kobayashi M, Mizokami M, Tanaka Y, Okanoue T, Minami M, Chayama K, Imamura M, et al. Measurement of hepatitis $B$ virus core-related antigen is valuable for identifying patients who are at low risk of lamivudine resistance. Liver Int. 2006;26:90-6.

37. Werle-Lapostolle B, Bowden S, Locarnini S, Wursthorn K, Petersen J, Lau G, Trepo C, Marcellin P, Goodman Z, Delaney WT, et al. Persistence of cccDNA during the natural history of chronic hepatitis $B$ and decline during adefovir dipivoxil therapy. Gastroenterology. 2004;126:1750-8.

38. Chan HL, Wong WW, Tse AM, Tse CH, Chim AM, Chan HY, Wong GL, Sung JJ. Serum hepatitis B surface antigen quantitation can reflect hepatitis B virus in the liver and predict treatment response. Clin Gastroenterol Hepatol. 2007;5:1462-8.

39. Volz T, Lutgehetmann M, Wachtler P, Jacob A, Quaas A, Murray JM, Dandri $M$, Petersen J. Impaired intrahepatic hepatitis B virus productivity contributes to low viremia in most HBeAg-negative patients. Gastroenterology. 2007;133:843-52.

40. Zoulim F. Assessment of treatment efficacy in HBV infection and disease. J Hepatol. 2006;44:S95-9.

41. Peters M. Actions of cytokines on the immune response and viral interactions: an overview. Hepatology. 1996;23:909-16.

42. Thimme R, Wieland S, Steiger C, Ghrayeb J, Reimann KA, Purcell RH, Chisari FV. CD8(+) T cells mediate viral clearance and disease pathogenesis during acute hepatitis B virus infection. J Virol. 2003;77:68-76.

43. Wang J, Du M, Huang H, Chen R, Niu J, Jiang J, Zhuang H, Lu F. Reply to: "serum HBV pgRNA as a clinical marker for cccDNA activity": Consistent loss of serum HBV RNA might predict the "para-functional cure" of chronic hepatitis B. J Hepatol. 2017;66:462-3.

44. Giersch K, Allweiss L, Volz T, Dandri M, Lutgehetmann M. Serum HBV pgRNA as a clinical marker for cccDNA activity. J Hepatol. 2017;66:460-2.
45. Liao H, Liu Y, Li X, Wang J, Chen X, Zou J, Li Q, Liu L, Wang J, Huang B, et al. Monitoring of serum HBV RNA, HBcrAg, HBsAg and anti-HBC levels in patients during long-term nucleoside/nucleotide analogue therapy. Antivir Ther. 2018.

46. Huang YW, Takahashi S, Tsuge M, Chen CL, Wang TC, Abe H, Hu JT, Chen DS, Yang SS, Chayama K, Kao JH. On-treatment low serum HBV RNA level predicts initial virological response in chronic hepatitis B patients receiving nucleoside analogue therapy. Antivir Ther. 2015;20:369-75.

47. Wang J, Shen T, Huang X, Kumar GR, Chen X, Zeng Z, Zhang R, Chen R, Li T, Zhang $T$, et al. Serum hepatitis B virus RNA is encapsidated pregenome RNA that may be associated with persistence of viral infection and rebound. J Hepatol. 2016;65:700-10.

48. Hatakeyama T, Noguchi C, Hiraga N, Mori N, Tsuge M, Imamura M, Takahashi S, Kawakami Y, Fujimoto Y, Ochi H, et al. Serum HBV RNA is a predictor of early emergence of the YMDD mutant in patients treated with lamivudine. Hepatology. 2007;45:1179-86.

\section{Ready to submit your research? Choose BMC and benefit from:}

- fast, convenient online submission

- thorough peer review by experienced researchers in your field

- rapid publication on acceptance

- support for research data, including large and complex data types

- gold Open Access which fosters wider collaboration and increased citations

- maximum visibility for your research: over $100 \mathrm{M}$ website views per year

At $\mathrm{BMC}$, research is always in progress.

Learn more biomedcentral.com/submissions 